\title{
Effect of relative humidity on the microbial and physicochemical characteristics of 'Samnamul' (Aruncus dioicus var. kamtschaticus) during storage
}

\author{
Ah-Na Kim ${ }^{1}$, Kyo-Yeon Lee ${ }^{1}$, Jin Yong Kang ${ }^{1}$, Muhammad Shafiur Rahman $^{2}$, \\ Ho Jin $\mathrm{Heo}^{1,2}$, Sung-Gil Choi ${ }^{1,2 *}$ \\ ${ }^{1}$ Division of Applied Life Science (BK21 Plus), Institute of Agriculture and Life Science, \\ Gyeongsang National University, Jinju 52828, Korea \\ ${ }^{2}$ Division of Food Science and Technology (Institute of Agriculture and Life Sciences), \\ Gyeongsang National University, Jinju 52828, Korea

\section{저장 중 상대습도가 눈개승마의 미생물학적 및 이화학적 품질 특성에 미치는 영향} \\ 김아나 ${ }^{1} \cdot$ 이교연 ${ }^{1} \cdot$ 강진용 $^{1} \cdot$ 샤피어라만 ${ }^{2} \cdot$ 허호진 $^{1,2} \cdot$ 최성길 ${ }^{1,2 *}$ \\ 1경상대학교 응용생명과학부 응용생명과학전공, ${ }^{2}$ 경상대학교 농화학식품공학과(농업생명과학연구원)
}

\begin{abstract}
The effect of relative humidity (11- 96\%) on the numbers of microorganisms, color values, total phenolic contents, antioxidant activities, and oxidative enzyme activities of 'Samnamul' (Aruncus dioicus var. kamtschaticus) was examined during storage at $10^{\circ} \mathrm{C}$. It was found that an increase in the relative humidity led to increases in the number of aerobic bacteria, yeast, and mold during storage, while the samples stored at a higher relative humidity exhibited lower $L$ and $b$ values, in addition to higher a values, thereby indicating progressive browning. Furthermore, the total phenolic contents and antioxidant activities decreased upon increasing the relative humidity during storage at $10^{\circ} \mathrm{C}$, and storage at a higher relative humidity resulted in increases in the oxidative enzyme activities (e.g., polyphenol oxidase and peroxidase activities) over 4 weeks. The obtained result therefore indicate that the low oxidative enzyme activities of samples stored at a low relative humidity restrict enzymatic oxidation and browning, thereby maintaining the sample color and nutritional quality. As a result, storage at a lower relative humidity is considerably effective for extending the shelf life of 'Samnamul'.
\end{abstract}

Key words : Aruncus dioicus var. kamtschaticus, 'Samnamul', relative humidity, storage, quality characteristics

서 론

눈개승마(Aruncus dioicus var kamtschaticus)는 고산지대 에서 자생하는 장미과(Rosaceae)의 다년생 초본으로서 삼 나물이라고 불리며, 높은 영양가와 더불어 특유한 관능성
에 따라 대표적인 산채자원으로 알려져 있다(Kwon 등, 2006; Song 등, 2015). 눈개승마는 탄수화물과 무기물함량 이 풍부해 수확하여 식용으로 널리 이용되고 있으며, 사포 닌(saponin), 살리실알데히드(salicylaldehyde), 인회분 지 질, 비타민 A, 칼슘(calcium) 등의 다양한 유효성분과 기능

*Corresponding author. E-mail : sgchoi@gnu.ac.kr, Phone :+82-10-7143-3100, Fax :+82-55-772-1909

Received 18 November 2019; Revised 10 December 2019; Accepted 10 December 2019.

Copyright (c) The Korean Society of Food Preservation.

This is an Open Access article distributed under the terms of the Creative Commons Attribution Non-Commercial License (http://creativecommons.org/licenses/by-nc/4.0) which permits unrestricted non-commercial use, distribution, and reproduction in any medium, provided the original work is properly cited. 
성 물질인 플라보노이드(flavonoid) 및 폴리페놀(polyphenol) 화합물 등을 다량함유하고 있어 고급 산채식물로 부각되 고 있다(Kim 등, 1998; Kim 등, 2011). 이에 따라 눈개승마 를 효율적으로 재배하기 위한 환경조절에 따른 생장에 관한 연구(Kim 등, 1998; Song 등, 2015; Nam 등, 2017; Lee 등, 2019)뿐만 아니라, 눈개승마의 산화방지 효과(Lee 등, 2005; Kim 등, 2011), DNA 손상 보호와 항염증 활성 (Zhang과 Kim, 2014), 고혈당에 의한 대사성 뇌신경 질환 예방(Park 등, 2017), 항혈전 활성(Kim과 Sohn, 2014) 등 여러 건강 기능적 효과를 평가하는 연구가 진행되고 있다.

최근에 화학비료나 농약을 이용한 재배채소의 수요가 감소하고, 자연산 산채류에 대한 관심이 증가하고 있으 며, 이에 따라 눈개승마를 포함한 산채류의 성분이나 생리 활성에 대한 연구가 활발히 진행되고 있다(Nam과 Baik, 2006). 이와 같이 산채식물의 체계적이고 지속적인 연구 결과를 통해, 농산물 수입 개방에 대응할 수 있는 중요한 농가소득 자원작물로써 대안이 될 수 있을 것으로 전망하 고 있다(Nam과 Baik, 2006). 하지만, 산채식물은 주로 신 선 상태로 소비되고 있으며, 이들은 생산시기가 한정되어 있어 가용시기가 제한적이고, 수확 후에도 활발한 증산 및 호흡작용으로 저장성이 매우 낮다. 또한, 산채식물의 높은 수분함량으로 인해 저장 중 미생물 증식에 따른 부패 와 효소 작용에 의한 갈변 및 영양성분 파괴가 급격히 진행되어 유통기한이 매우 짧은 문제점이 있다(Rhim과 Hwang, 1995). 현재까지 이러한 품질 열화를 방지하기 위한 수확 후 관리 방법으로 저온저장을 실시하고 있지만, 저장 중 주요 환경요인인 상대습도에 대한 연구는 전무한 실정이다. 일반적으로 상대습도는 공기 속에 있는 수증기 양과 그 온도에서의 포화수증기의 양과의 비를 말하는 것으로, 식품 내부의 수증기압이 주위 공기의 수증기 분압과 평형을 이루었을 때 주위 공기의 상대습도를 평 형상대습도(equilibrium relative humidity, ERH)라고 한다 (Choi, 2018). 실질적으로 평형상대습도의 수치는 그 상대 습도와 평형을 이루고 있는 식품 수분활성도(water activity, Aw)의 100 배를 말하며, 수분활성도는 저장 중 미생물의 번식과 효소반응 및 비효소적인 반응 등 여러 화학반응을 좌우함에 따라 품질에 직접적인 영향을 미치 는 주요 요인으로 알려져 있다(Choi, 2008). 따라서 수확 후 신선 산채식물의 유통 및 저장 중 최적 상대습도를 조성함으로써 위생적 안전성을 확보하고, 품질유지기한 을 연장하기 위한 연구가 필요한 실정이다.

본 연구에서는 대표적인 산채식물인 눈개승마의 안정 적 공급을 확보하기 위하여 상대습도에 따른 저장기간별 미생물학적 및 이화학적 특성변화를 분석하여 눈개승마 의 저장 시 적합한 상대습도를 구명하고자 하였다.

\section{재료 및 방법}

\section{실험 재료}

본 실험에 사용한 눈개승마는 강원도 태백시에 위치한 태백쌈채마을로부터 2018년 4월에 구입하였으며, 수확 당 시 재배지의 평균 기온 및 강수량은 각각 $10.12^{\circ} \mathrm{C}$ 와 8.59 $\mathrm{mm}$ 였다. 눈개승마의 줄기를 제거한 후 중량이 $0.25 \pm 0.01$ $\mathrm{g}$ 으로 균일한 것을 1 차 선별하였고, 조직의 물러짐이나 갈변 현상이 발견되지 않으며 벌레가 먹지 않은 눈개승마 를 2 차 선별한 직후 실험에 사용하였다. 연구에 사용된 시약 염화리튬(lithium chloride), 초산칼륨(potassium acetate), 염화마그네슘(magnesium chloride), 탄산칼륨(potassium carbonate), 질산마그네슘(magnesium nitrate), 요오드화칼 륨(potassium iodide), 황산암모늄(ammonium sulfate), 질산 칼륨(potassium nitrate), 과황화칼륨(potassium persulfate), 염화 제2철(ferric chloride), 염화나트륨(sodium chloride), 과산화수소(hydrogen peroxide)는 대정화학(Daejung Chem. Co., Ltd., Seoul, Korea)에서 구입하여 사용하였다. 또한, 폴린 시약(Folin \& Ciocalteu's phenol reagent), 갈산(gallic acid), 2,2-diphenyl-1-picrylhydrazyl(DPPH), 2,2'-azino-bis (3-ethylbenzothiazoline-6-sulfonic acid)(ABTS), diammonium salt, tripyridyltriazine(TPTZ), poly(vinylpolypyrrolidone), triton X-100, 카테 콜(catechol), p-페닐렌디아민(phenylenediamin)은 Sigma-Aldrich(St. Louis, MO, USA)사에서 구입 하여 사용하였다.

\section{상대습도에 따른 저장 방법}

여러 상대습도 $11-96 \%$ 의 조건을 맞추기 위해, 각각의 염을 포화용액 이상의 농도로 용해하여 포화상태를 만든 후 데시케이터 안에 넣어 상대습도를 조절하였다. 저장 시 외부온도 $10^{\circ} \mathrm{C}$ 에서 상대습도 $11 \%$ 는 $\mathrm{LiCl}, 23 \%$ 는 $\mathrm{KCH}_{3} \mathrm{CO}_{2}, 33 \%$ 는 $\mathrm{MgCl}_{2}, 43 \%$ 는 $\mathrm{K}_{2} \mathrm{CO}_{3}, 57 \%$ 는 $\mathrm{Mg}\left(\mathrm{NO}_{3}\right)_{2}$ $72 \%$ 는 $\mathrm{KI}, 82 \%$ 는 $\left(\mathrm{NH}_{4}\right)_{2} \mathrm{SO}_{4}, 96 \%$ 는 $\mathrm{KNO}_{3}$ 를 이용하여 제조하였다. 각 포화염 용액의 상대습도는 측정용기에서 시료를 평형수분함량에 도달시킨 후 수분활성도 측정기 (AQS-2, Nagy mess system, Gäufelden, Germany)를 이용하 여 수분활성도를 측정함으로써 이를 검증하였다. 상대습 도가 맞춰진 데시케이터 안에 멸균된 weighing dish를 넣고 시료 $10 \mathrm{~g}$ 을 배분한 뒤 $10^{\circ} \mathrm{C}$ 에서 $2,4,7,10,14$ 주간 저장하 여 실험에 사용하였다. 여러 상대습도에서 저장한 눈개승 마의 등온흡습곡선은 매일 무게를 측정함으로써 수분 이 동에 의한 시료 무게의 증감을 조사하였다. 흡습 또는 탈습 에 의한 무게의 증감이 더 이상 관찰되지 않는 점을 평형점 으로 보고, 이때의 수분함량을 측정하여 평형수분함량을 결정하였으며, 평형수분함량을 상대습도에 대해 도시하 
여 각 온도에서 등온흡습곡선을 도출하였다(Rhim, 1993). 또한 눈개승마의 평형수분함량은 상압 가열 건조법에 따 라 $105^{\circ} \mathrm{C}$ 에서 4 시간 동안 건조하여 측정하였다 $(\mathrm{AOAC}$, 1995).

\section{미생물 수}

상대습도에 따라 저장한 눈개승마의 미생물 수를 알아 보기 위해서 일반세균, 대장균군, 효모 및 곰팡이 수를 3 회 반복하여 측정하였다. 저장 직후 수분 보정한 약 1 $\mathrm{g} \mathrm{dw}$ (dry weight)의 시료를 채취하여 멸균된 stomacher bag 에 넣은 후 $0.85 \%$ 멸균생리식염수로 10 배 희석하여 stomacher로 2 분간 균질화하였다. 이후 10 배씩 단계별 희석하 여 시료를 준비하였으며, 희석한 시료 $1 \mathrm{~mL}$ 를 일반세균 Petrifilm ${ }^{\mathrm{TM}}$ aerobic count plate(3M Company, St. paul, MN, USA)에 접종하였다. 배지를 $35^{\circ} \mathrm{C}$ 에서 48 시간 배양하여 30 - 300개 사이의 colony 수를 측정하였다. 대장균군은 위의 방법과 동일하게 단계 희석하여 Petrifilm ${ }^{\mathrm{TM}}$ coliform count plate(3M Company, St. paul, MN, USA)에 접종하였고 $35^{\circ} \mathrm{C}$ 에서 24 시간 배양 후 기포를 가진 red colony만을 확인 하였다. 효모 및 곰팡이는 위의 방법과 동일하게 단계 희석 하여 Petrifilm ${ }^{\mathrm{TM}}$ yeast \& mold count plate(3M Company, St. paul, $\mathrm{MN}, \mathrm{USA}$ )에 접종하였고, $25^{\circ} \mathrm{C}$ 에서 5 일간 배양 후 green, yellow, pink 등의 모든 colony를 측정하였다. 일반 세균, 대장균군, 효모 및 곰팡이는 시료 $1 \mathrm{~g} \mathrm{dw}$ 당 colonyforming units(CFU)을 $\log$ 단위로 환산하여 표시하였다.

\section{색도}

상대습도에 따라 저장한 눈개승마의 색도 변화를 살펴 보기 위하여 시료를 투명 진공삼면접착봉투 $(0.07 \times 10 \times 15$ $\mathrm{mm})$ 에 진공포장한 후 백색지 위에 놓고 잎상부의 중심부 를 조건별로 동일한 위치에서 측정하였다. 표준백색판 $(\mathrm{L}=93.6, \mathrm{a}=0.31, \mathrm{~b}=0.32)$ 으로 보정된 색차계(Minolta CT-310, Minolta Co., Ltd., Osaka, Japan)를 이용하여 L(lightness, 명도), a(redness, 적색도) 및 b(yellowness, 황색도)값을 3회 반복 측정하였다(Hunter, 1975).

\section{총페놀 함량 분석}

상대습도에 따라 저장한 눈개승마의 총페놀 함량은 $\mathrm{Kim}$ 등(2003)의 방법을 참고 및 수정하여 실험을 진행하였 다. 즉, 저장 직후 수분 보정한 약 $1 \mathrm{~g} \mathrm{dw}$ (dry weight)의 시료에 추출용액 $80 \%$ 에탄올 $500 \mathrm{~mL}$ 를 가하여 균질기 (D-500, Wiggen Hauser, Berlin, Germany)로 10,000 rpm에 서 30 초간 균질한 후 $5^{\circ} \mathrm{C}$ 에서 $200 \mathrm{rpm}$ 으로 추출하였다. 추출물을 여과한 여과액 $1 \mathrm{~mL}$ 와 증류수 $9 \mathrm{~mL}$ 를 혼합 후 $1 \mathrm{~mL}$ 의 Folin \& Ciocalteu's phenol reagent를 첨가하여 실온 암실에서 5 분간 방치하였다. 그 후 $7 \%$ Sodium carbonate
$10 \mathrm{~mL}$ 와 증류수 $4 \mathrm{~mL}$ 를 첨가한 후 실온 암실에서 2 시간 방치하였으며, 분광광도계(UV-1800, Shimadzu Corporation, Kyoto, Japan)를 이용하여 $760 \mathrm{~nm}$ 에서 흡광도를 측정하였 다. 표준곡선은 gallic acid를 표준물질로 $0.025 \mathrm{mg} / \mathrm{mL}, 0.05$ $\mathrm{mg} / \mathrm{mL}, 0.1 \mathrm{mg} / \mathrm{mL}, 0.25 \mathrm{mg} / \mathrm{mL}, 0.5 \mathrm{mg} / \mathrm{mL}, 1 \mathrm{mg} / \mathrm{mL}$ 로 제조하여 흡광도를 측정하였으며, 총페놀 함량은 g gallic acid equivalent $(\mathrm{GAE}) / \mathrm{kg}$ dw로 나타내었다.

\section{항산화 활성 측정}

눈개승마의 항산화 활성을 측정하기 위해 저장 직후 수 분 보정한 약 $1 \mathrm{~g}(\mathrm{dw})$ 의 시료에 추출용액 $80 \%$ 에탄올 500 $\mathrm{mL}$ 를 가하여 균질기(D-500, Wiggen Hauser, Berlin, Germany)로 $10,000 \mathrm{rpm}$ 에서 30 초간 균질한 후 $5^{\circ} \mathrm{C}$ 에서 $200 \mathrm{rpm}$ 으로 추출하였으며, 이를 여과한 여과액을 이용하 였다. 항산화 활성 분석법으로는 $\mathrm{DPPH}$ 라디컬 소거능, $\mathrm{ABTS}$ 라디컬 소거능, FRAP 환원력을 실시하였으며, 모두 $\mathrm{g}$ trolox equivalent(TE) $/ \mathrm{kg} \mathrm{dw}$ 로 나타내었다.

$\mathrm{DPPH}$ 라디컬 소거 활성은 Blois(1996)의 방법을 변형하 여 실험을 진행하였다. $100 \mathrm{~mL}$ 의 에탄올에 $8 \mathrm{mg}$ 의 DPPH (Sigma, St. Louis, MO, USA)를 용해시켜 제조하였으며, 여과액을 $80 \%$ 에탄올로 4 배 희석한 추출액 $0.1 \mathrm{~mL}$ 를 $\mathrm{DPPH}$ 용액(OD: 1.000) $0.9 \mathrm{~mL}$ 와 혼합하여 실온 암실에서 30 분간 방치 후 분광광도계를 이용하여 $517 \mathrm{~nm}$ 에서 흡광 도를 측정하였다.

ABTS 라디컬 소거능은 Re 등(1999)의 방법을 변형하여 실험을 진행하였다. ABTS 용액은 $7 \mathrm{mM} \mathrm{ABTS} \mathrm{diammo-}$ nium salt와 $2.45 \mathrm{mM}$ potassium persulphate를 혼합 후 실온 암실에서 16 시간 동안 방치하여 제조하였다. 여과액 20 $\mu \mathrm{L}$ 와 $\mathrm{ABTS}$ 용액 $980 \mu \mathrm{L}$ 를 혼합하여 실온 암실에서 6분 동안 방치한 후 분광광도계를 이용하여 $734 \mathrm{~nm}$ 에서 흡광 도를 측정하였다.

FRAP(ferric ion reducing antioxidant power) 측정은 Benzie와 Strain(1996)의 방법을 변형하여 실험을 진행하였 다. 즉, $300 \mathrm{mM}$ sodium acetate buffer(pH3.6)와 $40 \mathrm{mM} \mathrm{HCl}$ 로 용해시킨 $10 \mathrm{mM}$ tripyridyltriazine(TPTZ), $20 \mathrm{mM} \mathrm{FeCl}_{3}$. $6 \mathrm{H}_{2} \mathrm{O}$ 을 제조하였고, 이를 각각 $10: 1: 1(\mathrm{v} / \mathrm{v} / \mathrm{v})$ 비율로 혼합하여 FRAP 용액을 제조하였다. 여과액을 $80 \%$ 에탄올 로 4배 희석한 추출액 $50 \mu \mathrm{L}$ 와 FRAP 용액 $1.5 \mathrm{~mL}$ 를 혼합하 였고, 이를 실온 암실에서 30 분간 방치한 후 분광광도계를 이용하여 $593 \mathrm{~nm}$ 에서 흡광도를 측정하였다.

\section{산화효소 활성}

상대습도에 따라 저장한 눈개승마의 산화효소 활성을 분석하기 위하여, 과채류의 주요 산화효소인 polyphenol oxidase(PPO)와 peroxidase(POD) 활성을 측정하였고, 효소 추출은 Eshghi 등(2014)의 방법을 변형하여 실험에 사용하 
였으며, 효소활성은 Terefe 등(2009)의 방법을 참고하여 측정하였다. 산화효소의 추출은 $4 \%(\mathrm{w} / \mathrm{v})$ poly(vinylpolypyrrolidone), $1 \%(\mathrm{w} / \mathrm{v})$ triton $\mathrm{X}-100,1 \mathrm{M} \mathrm{NaCl}$ 이 용해된 $0.2 \mathrm{M}$ sodium phosphate buffer(pH 6.5) $10 \mathrm{~mL}$ 에 동결건조 시료 $0.2 \mathrm{~g}$ 을 가한 후 균질기(D-500, Wiggen Hauser, Berlin, Germany)로 $10,000 \mathrm{rpm}$ 에서 30 초간 균질하였다. 이를 shaker를 이용하여 $200 \mathrm{rpm}$ 으로 $4^{\circ} \mathrm{C}$ 에서 2 시간 동안 추출 한 후, 이를 여과하여 효소용액으로 사용하였다. PPO 활성 측정시 사용되는 기질용액은 $0.05 \mathrm{M}$ sodium phosphate buffer(pH 6.5)에 $0.07 \mathrm{M}$ catechol를 용해하여 제조하였다. 효소용액 $75 \mu \mathrm{L}$ 에 기질용액 $3 \mathrm{~mL}$ 를 첨가한 후 분광광도계 (UV-1800, Shimadzu Corporation, Kyoto, Japan)의 kinetic mode를 이용하여 $420 \mathrm{~nm}$ 에서 10 분 동안 흡광도의 변화를 측정하였다. $\mathrm{POD}$ 활성은 $200 \mu \mathrm{L}$ 의 효소용액에 $1.5 \mathrm{~mL}$ 의 $0.05 \mathrm{M}$ sodium phosphate buffer( $\mathrm{pH}$ 6.5), $200 \mu \mathrm{L}$ 의 $1 \%$ p-phenylenediamin이 용해된 $0.05 \mathrm{M}$ sodium phosphate buffer(pH 6.5), $200 \mu \mathrm{L}$ 의 $1.5 \%$ hydrogen peroxide가 용해된 $0.05 \mathrm{M}$ sodium phosphate buffer $(\mathrm{pH}$ 6.5)를 첨가하여 분광광 도계(UV-1800, Shimadzu Corporation, Kyoto, Japan)의 kinetic mode를 이용하여 $485 \mathrm{~nm}$ 에서 10 분 동안 흡광도의 변화를 측정하였다. 모든 추출용액과 기질용액은 분석 직 전에 제조하여 사용하였고, 산화효소 활성 1 unit은 효소 추출액의 1 분당 0.001 의 흡광도의 변화인 $\mathrm{U} / \mathrm{g} / \mathrm{min} \mathrm{dw}$ 로 나타내었다.

\section{통계 분석}

실험결과는 3회 반복 실험하여 얻어진 평균 \pm 표준편차 로 나타내었고, 통계처리는 Window 용 SAS 9.4 version(v 9.4 version, SAS Institute Inc, Cary, NC, USA)을 이용하여 $\mathrm{p}<0.05$ 수준에서 이원배치 분산분석(two-way analysis of variance)을 실시하였으며, Duncan의 다중 범위 검정법 (Duncan's multiple range test)으로 유의성을 검증하였다.

\section{결과 및 고찰}

\section{등온흡습곡선}

식품 속에 함유되어 있는 수분은 온도가 일정한 상태 하에서 외부의 상대습도에 따라 탈습 및 흡습과정을 통해 일정한 평형상태에 도달하게 되는데, 이때 상대습도와 식 품속의 평형수분함량간의 관계를 등온흡습(탈습)곡선이 라고 한다. 등온흡습곡선을 통해 식품의 수분흡습특성을 규명할 수 있으며, 저장성을 예측할 수 있는 기초자료로 활용될 수 있다(Probert, 2003). 따라서 본 연구에서는 냉장 온도 $10^{\circ} \mathrm{C}$ 에서 여러 상대습도에 따라 저장한 눈개승마의 무게변화를 측정하였다. 눈개승마의 경우 저장 7일 후 평 형수분함량에 도달하였으며, 그에 따라 눈개승마의 등온
흡습곡선을 도출하였다(Fig. 1). 그 결과, 눈개승마의 등온 흡습곡선은 전형적인 시그모이드곡선(sigmoid curve, S-curve) 형태를 보이는 것으로 나타났으며, 상대습도가 $11 \%$ 부터 $93 \%$ 로 증가함에 따라 평형수분함량이 $5.10 \%$ 에 서 $53.55 \%$ 로 증가하였다. 즉, 상대습도 $11 \%$ 에서 $57 \%$ 까지 는 눈개승마의 평형수분함량이 완만하게 증가하였다가 $57 \%$ 에서 $82 \%$ 범위에서는 그 증가율이 다소 높았고, $82 \%$ 에서 $96 \%$ 의 상대습도에서는 수분함량이 급격하게 증가하 는 것으로 나타났다. 식품의 등온흡습곡선은 제 1 형, 제 2 형, 제 3 형으로 구분할 수 있으며, 제 1 형 영역의 평형수분함량 은 단분자층 형성 수분함량이나 그보다 낮은 수분함량을 지니므로 강한 이온결합을 형성하고 있는 결합수이다. 또 한 제 2 형 영역은 수소결합에 의해 결합되어 있는 다분자층 형성 수분함량 범위의 영역이며, 제3형 영역은 자유로운 유리수 상태로 다분자층 형성 수분함량보다 많은 모세관 응고영역이다(Rhee과 Maeng, 1983). 따라서 본 결과를 통 해 상대습도에 따라 눈개승마에 존재하는 수분이 화학반 응, 효소반응, 미생물 증식에 미치는 영향과 그 상관관계를 규명할 수 있을 것으로 생각된다.

\section{미생물 수}

냉장온도에서 저장기간별 상대습도에 따른 눈개승마의 대장균군, 일반세균, 효모, 곰팡이 수를 분석하였으며, 그 결과는 Fig. 2와 같다. 수확 직후 눈개승마의 일반세균, 효모 및 곰팡이 수는 각각 $5.84 \pm 0.16,5.78 \pm 0.12,5.97 \pm 0.17$ $\log \mathrm{CFU} / \mathrm{g}$ 수준으로 검출되었고, 저장기간 동안 눈개승마 의 대장균군은 검출되지 않는 것으로 나타났다. 일반세균, 효모 및 곰팡이 분석 결과, 모든 저장기간에서 상대습도가 증가함에 따라 미생물 수가 유의적으로 증가하는 것으로

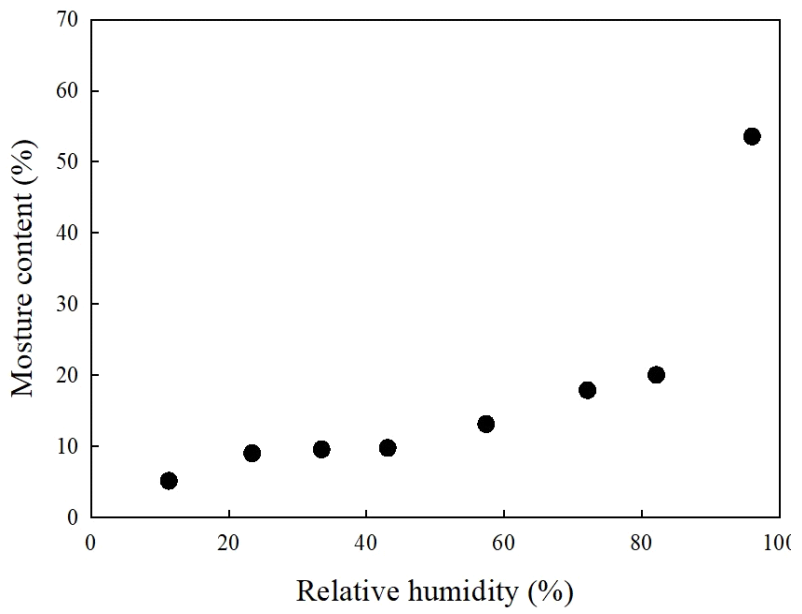

Fig. 1. Moisture sorption isotherm of Aruncus dioicus var kamtschaticus at $10^{\circ} \mathrm{C}$. 
(A)

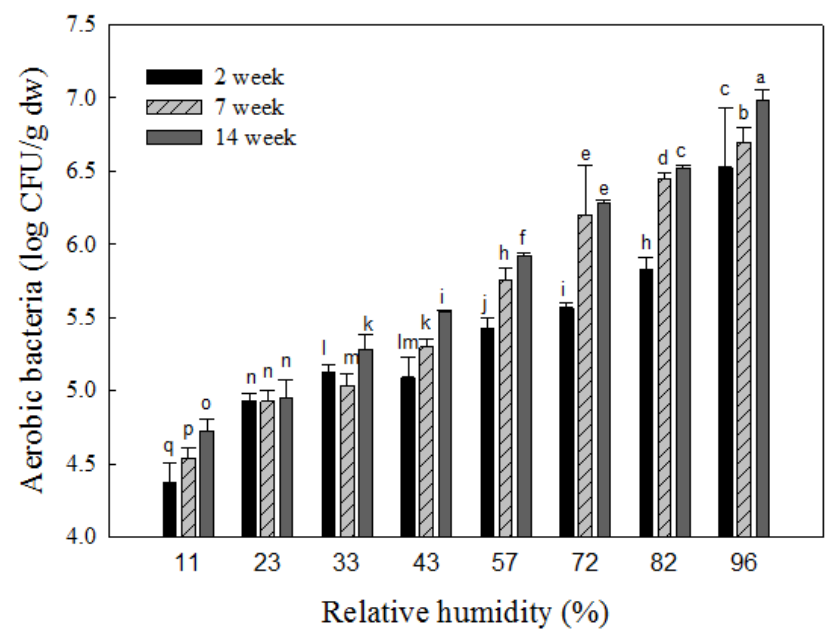

(B)

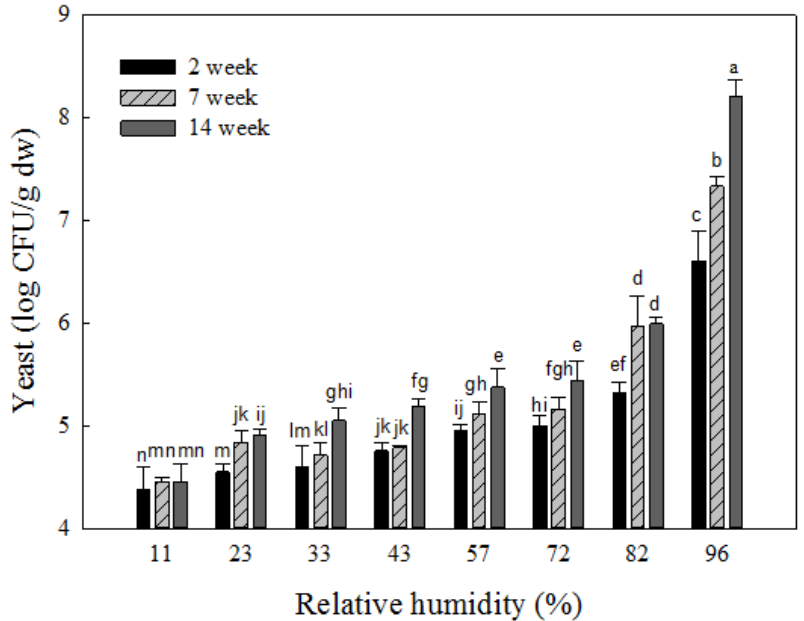

(C)

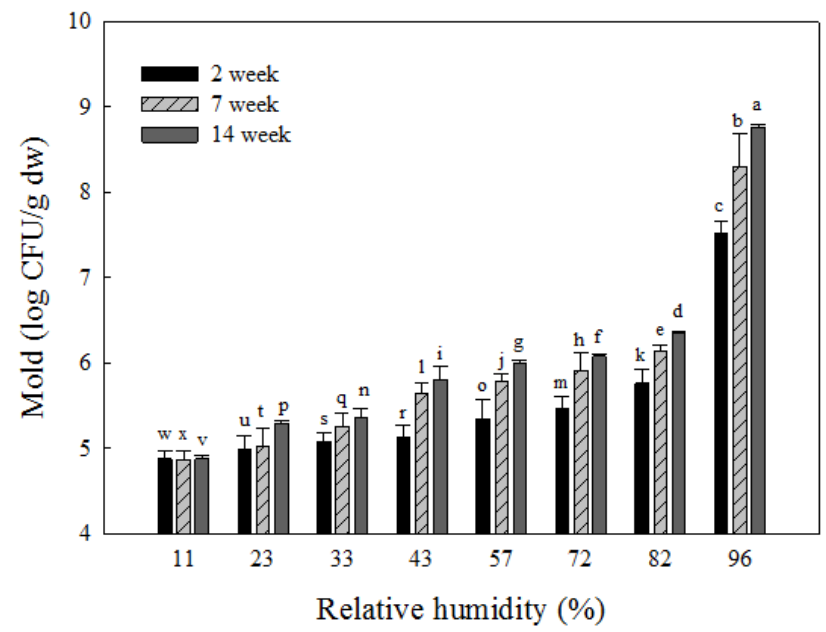

Fig. 2. Changes in the number of (A) aerobic bacteria, (B) yeast, and (C) mold of Aruncus dioicus var. kamtschaticus stored at different relative humidities ranged from 11 to $96 \%$ for 14 week at $10^{\circ} \mathrm{C}$.

Different letters indicate significant differences by Duncan's multiple range test $(p<0.05)$.

나타났다. 이는 저장 시 상대습도가 높을수록 식품 미생물 수가 증가했다고 보고한 여러 연구결과와 일치하는 것으 로 나타났다(Kwak 등, 1998; Kim 등, 2017). 눈개승마의 저장 전 미생물 수와 비교했을 때, 저장 14 주차 동안 $43.1 \%$ 이하의 상대습도에서 저장한 경우 일반세균 수가 다소 감소하거나 변화가 없는 것으로 나타났으며, 상대습도의 증가에 따라 선형적으로 미생물 수가 증가하여 14주차에 서 $6.99 \log \mathrm{CFU} / \mathrm{g}$ 수준으로 나타났다. 효모 및 곰팡이의 경우에는 상대습도 $72 \%$ 이하에서 저장했을 때 저장 전에 비해 미생물 수가 감소 또는 유지되는 것을 확인할 수 있었으며, 상대습도 $11 \%$ 에서 $82.1 \%$ 까지는 선형적으로 증 가하였다가 상대습도 $96.0 \%$ 에서 미생물 수가 각각 8.21 $\log \mathrm{CFU} / \mathrm{g}, 8.76 \log \mathrm{CFU} / \mathrm{g}$ 수준으로 급격하게 증가하는
것으로 나타났다. 일반적으로 미생물은 수분활성도가 0.80 - 0.90의 환경에서 생육하고 있으며, 효모의 경우에 성장이 가능한 수분활성도의 범위는 $0.88-0.92$ 이지만 일 부 내삼투압성 효모(osmphilic yeast)의 경우에는 매우 낮은 수분활성도인 Aw 0.80 이하에서도 성장을 계속할 수 있으 며, 곰팡이의 성장가능 수분활성도 범위는 0.70 에서 0.95 라고 알려져 있다(Troller와 Christian, 1978). 반면에, 낮은 상대습도에서 미생물 수가 감소되거나 증식이 억제되는 현상은 삼투압 변화(osmotic stress), 세포내부의 효소합성, 효소활성 등과 같은 대사활동이 변화되기 때문으로 보 고되고 있다(Brown, 1976). 이에 따라 Kim 등(2017)은 낮은 상대습도에서 저장 시 대부분의 미생물의 증식이 억제되므로 식품의 위생적인 보관을 위해서는 저장 중 
상대습도의 관리가 매우 중요하다고 보고하였다. 결과적 으로 눈개승마의 위생적 안정성을 유지하기 위해 낮은 상대습도에서 눈개승마를 냉장저장하는 것이 중요할 것 으로 생각된다.
색도

냉장온도에서 저장기간별 상대습도에 따른 눈개승마의 주요 품질지표인 색도를 분석하였으며, 그 결과는 Fig. 3과 같다. 모든 저장기간에서 상대습도가 높아질수록 눈개승

(A)

\begin{tabular}{|c|c|c|c|c|c|c|c|c|}
\hline \multirow{2}{*}{$\begin{array}{l}\text { Storage } \\
\text { period } \\
\text { (week) }\end{array}$} & \multicolumn{8}{|c|}{ Relative humidity $(\%)$} \\
\hline & 11 & 23 & 33 & 43 & 57 & 72 & 82 & 96 \\
\hline 14 & & & & & & & & \\
\hline
\end{tabular}

(B)

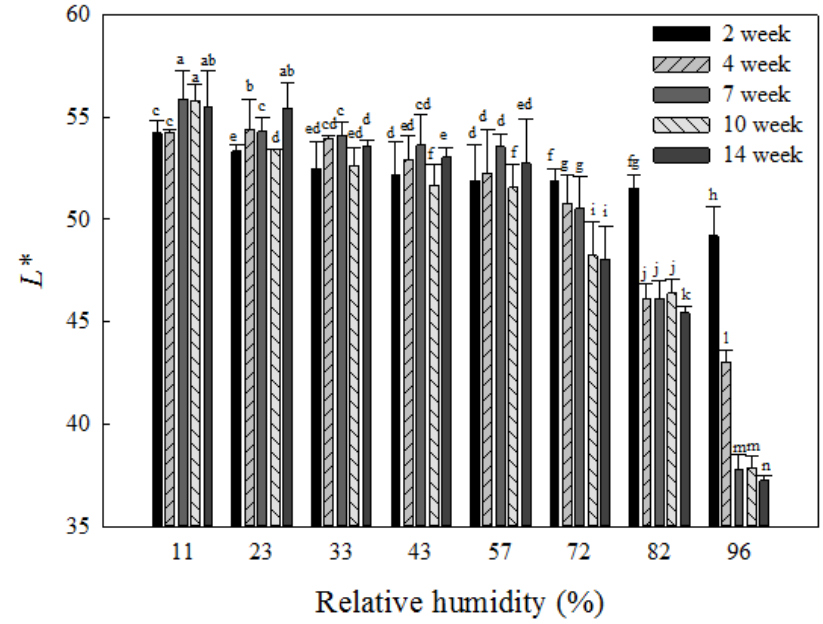

(C)

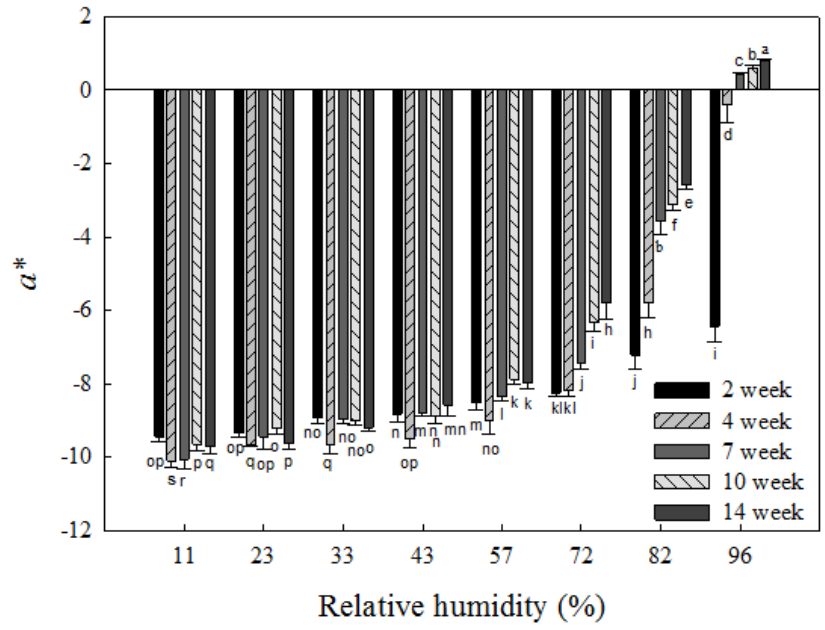

(D)

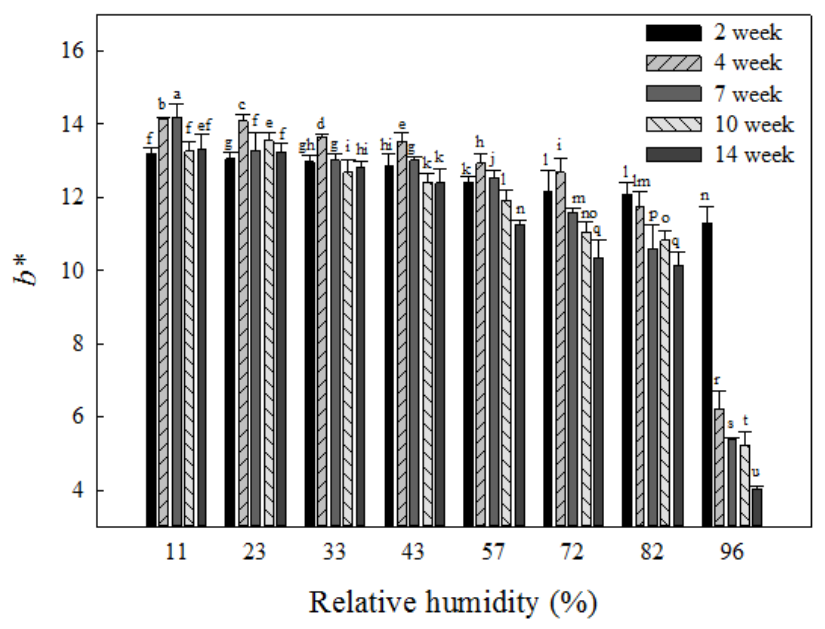

Fig. 3. Changes in (A) appearance and color values such as (B) L, (C) a, and (D) b of Aruncus dioicus var. kamtschaticus stored at different relative humidities ranged from 11 to $96 \%$ for 14 week at $10^{\circ} \mathrm{C}$.

Different letters indicate significant differences by Duncan's multiple range test $(\mathrm{p}<0.05)$. 
마의 $\mathrm{L}$ 값과 $\mathrm{b}$ 값은 감소하였고, $\mathrm{a}$ 값은 유의적으로 증가하 는 경향을 가지는 것으로 나타났다. 특히 저장 14 주차에서 상대습도 $11 \%$ 와 $23 \%$ 에서 저장한 눈개승마의 $\mathrm{L}, \mathrm{a}, \mathrm{b}$ 값의 유의적인 차이는 나타나지 않았지만, $33.5 \%$ 이상부터 $96.0 \%$ 까지 상대습도가 높아질수록 유의적으로 L값 및 b값 이 감소하고, a값이 증가하는 것을 확인할 수 있었다. 일반 적으로 녹색 과채류의 경우 $\mathrm{L}$ 값 및 $\mathrm{b}$ 값의 감소와 $\mathrm{a}$ 값의 증가는 chlorogphyll 파괴 또는 페놀성 화합물의 산화반응에 의한 색의 갈변을 나타내는 지표로 알려져 있다(Mosquera 와 Guerrero, 1995; Kim 등, 2015; Kim 등, 2017). 이에 따라 저장 시 높은 상대습도는 눈개승마의 갈변도를 촉진하는 것으로 나타났다. 따라서 색도의 결과는 상대습도에 따라 저장 14 주 후의 외관의 결과와 일치하는 것으로 나타났다. 또한, 상대습도 $72 \%$ 이상에서는 저장기간에 따라 상대습 도가 높아질수록 $\mathrm{L}$ 값 및 $\mathrm{b}$ 값이 감소하고 $\mathrm{a}$ 값이 증가함으로 써, 갈변현상이 빠르게 진행되는 것으로 나타났다. 저장 중 상대습도에 따른 식품의 수분활성도는 효소적 및 비효 소적 갈변반응에 상당한 영향을 미친다고 보고되고 있으 며(Kim 등, 1984; Jang 등, 2007; Lee 등, 2009), 본 연구결과 와 같이 Kim 등(1997)은 수분활성도가 높아짐에 따라 건대 추의 갈변이 증가하는 경향으로 나타났다고 보고하였다. 반면에, Jang 등(2007)은 통고추를 상대습도에 따라 저장했 을 때 $32 \%$ 이하의 상대습도에 저장한 경우 탈색현상이 나타 났으며, $51 \%$ 상대습도에서의 저장이 최적 저장 상대습도라 고 보고하였다. Agudelo Laverde(2011) 등은 배와 멜론을 여러 상대습도에 따라 저장한 결과 각각 $75 \%, 84 \%$ 의 수분활 성도에서 가장 높은 갈변이 나타났다고 보고하였다. 따라서 식품마다 제각기 가지는 성분 및 특성에 따라서 저장 중 적정 저장 상대습도가 다른 것으로 판단되며, 품질 저하를 효과적으로 방지할 수 있는 최적 상대습도를 도출하는 것이 중요할 것으로 생각된다. 본 연구결과를 통해 눈개승마의 경우 저장 중 상대습도가 낮을수록 저장 중 눈개승마의 갈변현상을 억제할 수 있는 것으로 나타났다.

\section{총페놀 함량 및 항산화 활성}

냉장온도에서 저장기간별 상대습도에 따른 눈개승마의 총페놀 함량 및 항산화 활성을 분석하였으며, 그 결과는 Fig. 4와 같다. 눈개승마의 항산화 활성은 $\mathrm{DPPH}$ 라디컬 소거능, $\mathrm{ABTS}$ 라디컬 소거능, $\mathrm{FRAP}$ 으로 3 가지 분석법을 실시하였다. 저장 중 상대습도가 높아질수록 총페놀 함량 및 항산화 활성이 유의적으로 감소하는 것으로 나타났다. 저장기간 2주차에서 14 주차로 경과함에 따라 상대습도 $11 \%$ 에 저장한 눈개승마의 총페놀 함량 및 항산화 활성은 $94.81-87.83 \%$ 수준으로 가장 높게 유지되었고, 상대습도 $96 \%$ 에 저장 시 $14.72-0 \%$ 수준으로 가장 급격하게 감소하 는 것으로 나타났다. 즉, 저장기간이 지남에 따라 모든
상대습도에서 저장한 눈개승마의 총페놀 함량 및 항산화 활성이 감소하는 경향을 가지는 것으로 나타났으며, 상대 습도가 높을수록 저장기간에 따른 총페놀 함량 및 항산화 활성의 감소폭이 증가하는 것으로 나타났다. Moraga 등 (2012)은 상대습도에 따라 6개월간 저장한 포도분말의 총 페놀 함량 및 항산화 활성을 분석했을 때 상대습도가 높을 수록 함량 및 활성이 감소하였다고 보고하였다. 또한, Lavelli와 Vantaggi(2009)등은 상대습도가 증가함에 따라 사과에 존재하는 페놀성 화합물 함량이 감소되며, 상대습 도가 높을수록 저장기간에 따른 감소속도가 증가했고, 이 에 따라 항산화 활성 또한 동일한 결과를 가지는 것으로 보고하였다. 따라서 총페놀 함량 및 항산화 활성의 감소를 높게 유지하기 위해서, 낮은 상대습도에서 눈개승마를 저 장하는 것이 중요할 것으로 생각된다.

\section{산화효소 활성}

냉장온도에서 저장기간별 상대습도에 따른 눈개승마의 산화효소 활성을 분석하였으며, 그 결과는 Fig. 5 와 같다. 과채류의 대표적인 산화효소로는 polyphenol oxidase(PPO) 와 peroxidase(POD)로 산소 존재 하에서 페놀 화합물의 산 화 및 갈변을 유도하는 것으로 알려져 있다(Tomas-Barberan 과 Espin, 2001). 저장 4주차까지 상대습도가 감소할수록 $\mathrm{PPO}$ 및 POD 활성이 유의적으로 감소하는 것으로 나타났 다. 이러한 수분활성도의 감소는 효소활성을 감소시키며, 일정수준 이하의 수분활성도는 수분이 효소 및 화학반응 을 일으키는 용매로써 작용할 수 없게 하기 때문으로 생각 된다(Lavelli와 Vantaggi, 2009). 반면에 상대습도 $96 \%$ 에서 저장한 눈개승마의 산화효소 활성은 저장 7주차 이후 급격 하게 감소하여 더 낮은 상대습도에서 저장했을 때의 산화 효소 활성보다 낮은 수준으로 활성이 감소하는 것으로 나타났다. Fevrier 등(2017)은 급격한 산화반응 이후 PPO 활성은 감소한다고 보고하였으며, Golan-Goldhirsh 등 (1984)은 PPO 활성은 기질로써 작용하는 폴리페놀 화합물 함량에 의존한다고 보고하였다. 본 연구결과에서 $96 \%$ 의 상대습도에서 저장한 눈개승마의 총페놀 함량은 저장 7 주 차 이후부터 급격하게 감소하며(Fig. 4), 이는 곧 산화효소 가 활성화될 수 있는 기질의 농도가 감소하였기 때문에 활성이 급격하게 감소한 것으로 생각된다. 또한, 모든 상대 습도에서 2주에서 7주까지 저장기간이 지남에 따라 산화 효소 활성이 감소하는 경향으로 나타났다. 이는 상대습도 에 따라 저장되면서 평형수분함량에 도달함으로써 탈습 현상으로 인해 용매로써 작용하는 수분의 양이 적어졌기 때문에 효소활성이 저하된 것으로 생각된다. 따라서 낮은 상대습도에서의 저장은 눈개승마의 산화효소 활성을 억 제함으로써, 페놀성 화합물의 산화를 방지함과 동시에 갈 변현상을 억제하고, 총페놀 화합물 및 항산화 활성을 높게 
(A)

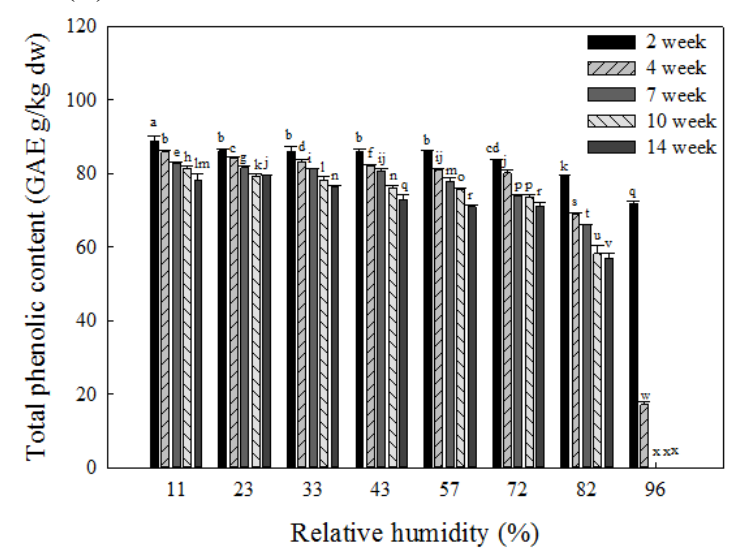

(C)

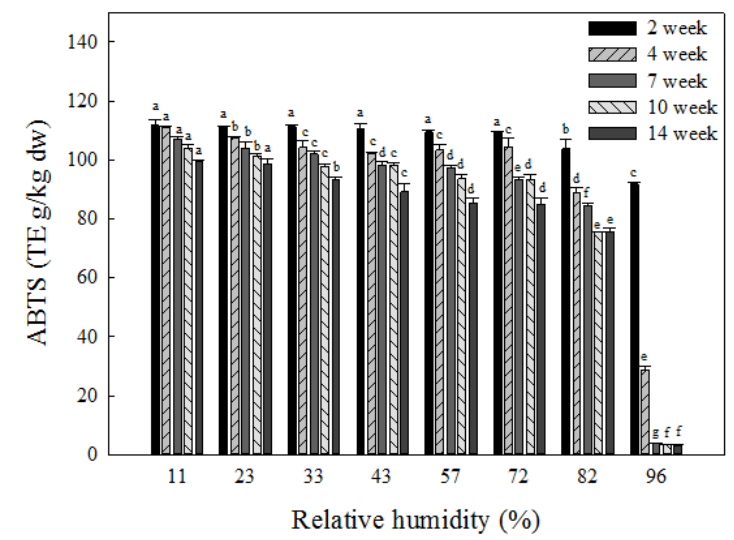

(B)

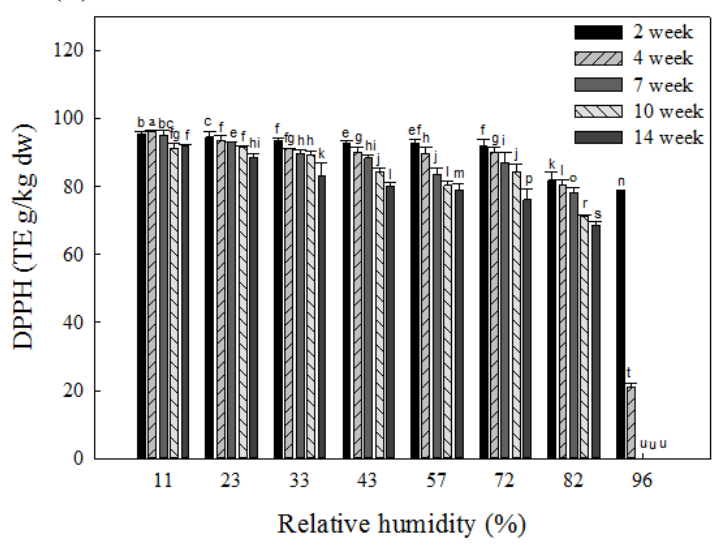

(D)

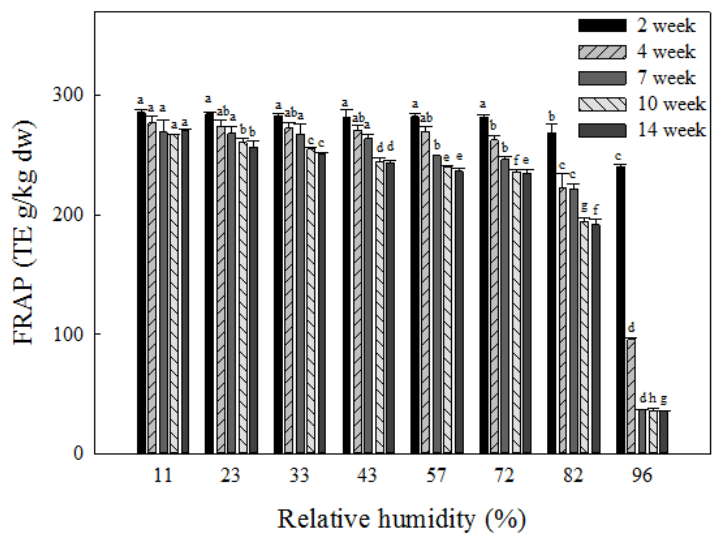

Fig. 4. Changes in color values such as (A) Total phenolic content, (B) DPPH radical scavenging activity, (C) ABTS radical scavenging activity, and (D) FRAP assay of Aruncus dioicus var. kamtschaticus stored at different relative humidities ranged from 11 to $96 \%$ for 14 week at $10^{\circ} \mathrm{C}$.

Different letters indicate significant differences by Duncan's multiple range test $(p<0.05)$.
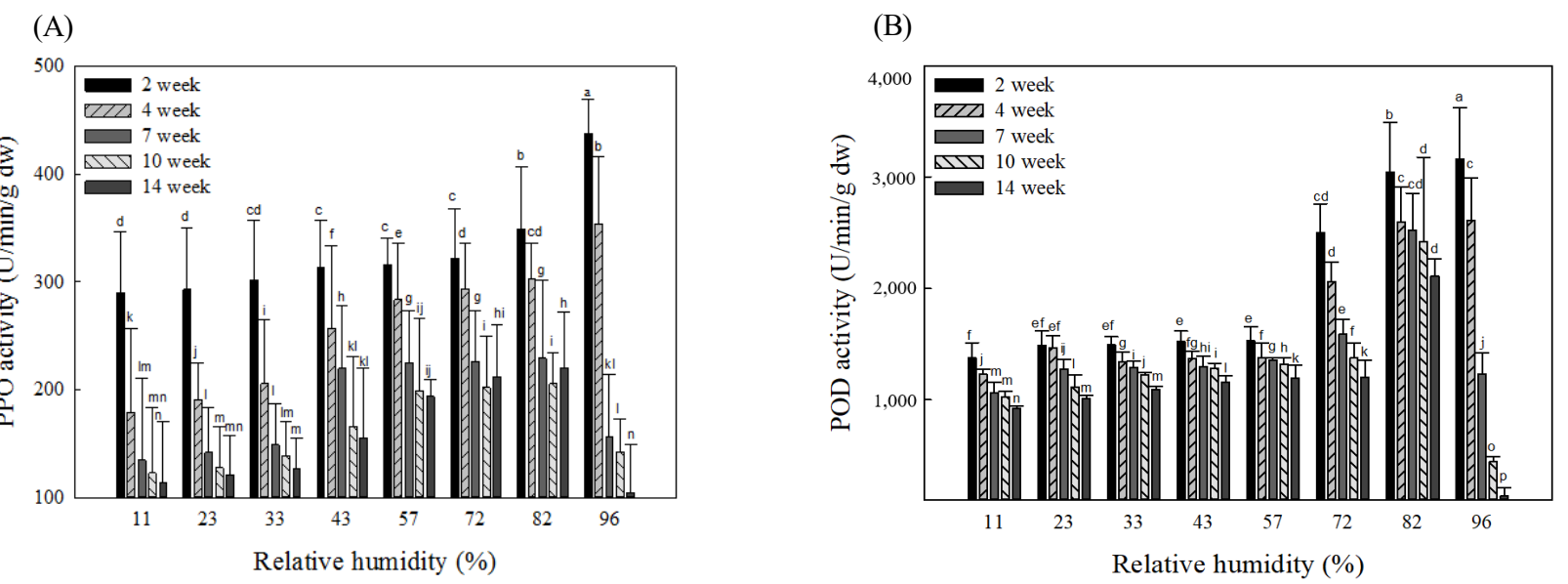

Fig. 5. Changes in oxidative enzyme activities such as (A) polyphenoloxidase and (B) peroxidase of Aruncus dioicus var. kamtschaticus stored at different relative humidities ranged from 11 to $96 \%$ for 14 week at $10^{\circ} \mathrm{C}$.

Different letters indicate significant differences by Duncan's multiple range test $(p<0.05)$. 
유지시켜줄 수 있는 것으로 생각된다.

\section{요 약}

대표적인 산채식물인 눈개승마(삼나물)는 생산시기가 한정되어 있어 가용시기가 제한적이고, 높은 수분함량과 수확 후 활발한 증산 및 호흡작용에 의해 저장성이 매우 낮아 유통기한이 매우 짧은 문제점이 있다. 따라서 눈개승 마의 안정적 공급을 확보하기 위해서 수확 후 관리 방법으 로 주요 저장 환경요인인 상대습도에 따른 미생물학적 및 이화학적 특성변화를 분석하였다. 이를 위해 $11-96 \%$ 상대습도 범위에서 14 주간 냉장저장을 실시하였으며, 이 에 따른 등온흡습곡선을 도출하였고, 미생물 수, 색도, 총페놀 함량 및 항산화 활성, 산화효소 활성을 분석하였 다. 그 결과 저장 중 상대습도가 높을수록 일반세균, 효모 및 곰팡이 수가 유의적으로 증가하는 것으로 나타났으며, 이는 눈개승마의 위생적 안전성을 확보하기 위해서는 낮 은 상대습도에서 저장하는 것이 중요한 것으로 나타났다. 또한, 높은 상대습도에서 저장 시 산화효소인 $\mathrm{PPO}$ 와 $\mathrm{POD}$ 활성이 높아짐에 따라 눈개승마에 존재하는 폴리페놀 화 합물의 산화 및 효소적 갈변반응이 촉진되며, 이에 따라 색도의 경우 상대습도가 높을수록 $\mathrm{L}$ 값 및 $\mathrm{b}$ 값이 감소하고 $\mathrm{a}$ 값이 증가하여 갈변현상이 심화되는 것으로 나타났으 며, 동시에 총페놀 함량 및 항산화 활성이 감소하는 것으 로 나타났다. 결과적으로 저장 중 상대습도는 눈개승마의 미생물학적 및 이화학적 품질 특성에 매우 큰 영향을 미치 는 것으로 나타났으며, 낮은 상대습도에서의 저온저장은 미생물의 증식과 산화효소 활성을 억제함으로써 눈개승 마의 품질유지기한을 연장하는데 효과적인 것으로 생각 된다.

\section{감사의 글}

본 논문은 산림청(한국임업진흥원) 산림과학기술 연구 개발사업('2017028A00-1919-BA01')의 지원에 의하여 이 루어진 것입니다.

\section{Conflict of interests}

The authors declare no potential conflict of interest.

\section{ORCID}
Ah-Na Kim
https://orcid.org/0000-0002-8390-0041
Sung-Gil Choi
https://orcid.org/0000-0003-2593-972X

\section{References}

Agudelo Laverde LM, Acevedo NC, Schebor C, Buera MP. Integrated approach for interpreting browning rate dependence with relative humidity in dehydrated fruits. LWT-Food Sci Technol, 44, 963-968 (2011)

AOAC. Official Methods of Analysis. 16th ed, Association of Official Analytical Chemists, Washington DC, USA (1995)

Benzie IFF, Strain JJ. The ferric reducing ability of plasma (FRAP) as a measure of "antioxidant power": The FRAP assay. Anal Biochem, 239, 70-76 (1996)

Blois MA. Antioxidant determination by the use of a stable free radical. Nature, 181, 1199-1200 (1958)

Brown AD. Microbial water stress. Bacteriol Rev, 40, 803-846 (1976)

Choi BM. Desorption EMC/ERH of soybean. Korean J Food Preserv, 15, 74-78 (2008)

Choi BM. Equilibrium moisture content/equilibrium relative humidity of barley. Korean J Food Preserv, 25, 543-548 (2018)

Eshghi S, Hashemi M, Mohammadi A, Badii F, Mohammadhoseini Z, Ahmadi K. Effect of nanochitosan-based coating with and without copper loaded on physicochemical and bioactive components of fresh strawberry fruit (Fragaria $\times$ Ananassa Duchesne) during storage. Food Bioproc Tech, 7, 2397-2409 (2014)

Fevrier H, Le Quere JM, Le Bail G, Guyot S. Polyphenol profile, $\mathrm{PPO}$ activity and $\mathrm{pH}$ variation in relation to colour changes in a series of red-fleshed apple juices. LWT-Food Sci Technol, 85, 353-362 (2017)

Golan-Goldhirsh A, Whitaker JR, Kahn V. Relation between structure of polyphenl oxidase and prevention of browning. In: Nutritional and Toxicological Aspects of Food Safety, Fredman M (Editor), Plenum Press, New York, USA, p 437-456 (1984)

Greenspan L. Humidity fixed points of binary saturated aqueous solutions. J Res Natl Bur Stand Sect A, 81, 89-96 (1977)

Hunter RS. Scales for measurement of solour difference. In: The Measurements of Appearance, Hunter RS (Editor), Wiley, New York, USA, p 133-140 (1975)

Jang SW, Cha KH, Yang JC, Lee CH, Shin SK, Jo CJ. Changes of water activity and physico-chemical properties of burley tobacco as affected by storage and moisture contents. J Korean Soc Tobacco Sci, 29, 59-65 (2007) 
Kim A, Kang SW, Heo HJ, Chun JY, Choi SG. Effect of heat treatment on quality characteristics and antioxidant activity of Korean traditional actinidia (Actinidia arguta) cultivars puree. Korean J Food Preserv, 22, 408-420 (2015)

Kim AN, Ko HS, Lee KY, Rahman MS, Heo HJ, Choi SG. The effect of superheated steam drying on physicochemical and microbial characteristics of Korean traditional actinidia (Actinidia arguta) leaves. Korean J Food Preserv, 24, 464-471 (2017)

Kim DO, Jeong SW, Lee CY. Antioxidant capacity of phenolic phytochemicals from various cultivars of plums. Food Chem, 81, 321-326 (2003)

Kim HK, Park MH, Shin DH, Min BY. Color changes and sorption characteristics of whole red pepper with relative humidity and temperature. Korean J Food Sci Technol, 16, 437-442 (1984)

Kim JY, Bae YM, Hyun JE, Kim EM, Kim JC, Lee SY. Microbiological quality of dried and powdered foods stored at various relative humidities. J East Asian Soc Diet Life, 27, 576-582 (2017)

Kim MS, Kim KH, Jo JE, Choi JJ, Kim YJ, Kim JH, Jang SA, Yook HS. Antioxidative and antimicrobial activities of Aruncus dioicus var. kamtschaticus Hara extracts. J Korean Soc Food Sci Nutr, 40, 47-55 (2011)

Kim MS, Sohn HY. Anti-thrombosis activity of the aerial part of Aruncus dioicus var. kamtschaticus. J Life Sci, 24, 515-521 (2014)

Kim SK, Lee SC, Lee SP, Choi BS. Effects of planting date and fertilization amounts on growth and yield of Aruncus dioicus var. kamtsccus Hara. Korean J Plant Res, 11, 142-145 (1998)

Kim YS, An DS, Woo KL, Lee DS. Moisture sorption isotherm and quality deterioration of dry jujube. Korean J Food Preserv, 4, 33-38 (1997)

Kwak YS, Shin HJ, Choo JJ. Effects of water activity on microbial growth in herb extract. J Fd Hyg Safety, 13, 77-82 (1998)

Kwon JW, Park JH, Kwon KS, Kim DS, Jeong JB, Lee HK, Sim YE, Kim MS, Youn JY, Chung GY, Jeong HJ. Effect of shading practices on the chemical compounds and antioxidant in Arucus dioicus. Korean J Plant Res, 19, 1-7 (2006)

Lavelli V, Vantaggi C. Rate of antioxidant degradation and color variations in dehydrated apples as related to water activity. J Agric Food Chem, 57, 4733-4738 (2009)
Lee JM, Lim SW, Cho SH, Choi SG, Heo HJ, Lee SC. Effect of relative humidity and storage temperature on the quality of green tea powder. J Korean Soc Food Sci Nutr, 38, 83-88 (2009)

Lee KC, Han SK, Kwon YH, Jeon SR, Lee CW, Seo DJ, Park WG. Effects of shading treatment on growth and physiological characteristics of Aruncus dioicus var. kamtschaticus (Maxim.) H. Hara seedling. Korean J Medicinal Crop Sci, 27, 30-37 (2019)

Lee SO, Lee HJ, Yu MH, Im HG, Lee IS. Total polyphenol contents and antioxidant activities of methanol extracts from vegetables produced in Ullung Island. Korean J Food Sci Technol, 37, 233-240 (2005)

Moraga G, Igual M, Garcia-Martinez E, Mosquera LH, Martinez-Navarrete N. Effect of relative humidity and storage time on the bioactive compounds and functional properties of grapefruit powder. J Food Eng, 112, 191-199 (2012)

Mosquera IM, Guerrero LG. Disappearance of chlorophylls and carotenoids during the ripening of the olive. J Sci Food Agric, 69, 1-6 (1995)

Nam HH, Lee JH, Choo BK. Effect of $\mathrm{NaCl}$ Treatment on growth and physiologycal activity of Aruncus dioicus var. kamtschaticus (Maxim.) H. Hara. Korean J Org Agric, 25, 789-804 (2017)

Nam Y, Baik J. Status of research and possibility of development about endemic wild vegetables in Korea. $\mathrm{J}$ People Plants Envion, 8, 1-10 (2005)

Park SB, Lee U, Kang JY, Kim JM, Park SK, Park SH, Choi SG, Heo HJ. Protective effects of Aruncus dioicus var. kamtschaticus extract against hyperglycemic-induced neurotoxicity. Korean J Food Sci Technol, 49, 668-675 (2017)

Probert RJ. Seed viability under ambient conditions, and the importance of drying. In: Seed Conservation: Turning Science into Practice, Smith RM, Dickie JB, Linington SH, Pritchard HW, Provert RJ (Editors), Royal Botanic Gardens, Kew, London, UK, p 337-365 (2003)

Re R, Pellegrini N, Proteggente A, Pannala A, Yangc M, Rice-Evans C. Antioxidant activity applying an improved ABTS radical cation decolorization assay. Free Radical Bio Med, 26, 1231-1237 (1999)

Rhee C, Maeng YS. Water vapor sorption behavior of some agricultural products produced in Korea. Korean J Food Sci Technol, 15, 315-320 (1983)

Rhim JW. Study on the moisture sorption characteristics of 
seasoned dried laver. J Korean Soc Food Sci Nutr, 22, 476-483 (1993)

Rhim JW, Hwang KT. Study on the drying characteristics of wild vegetables. Korean J Food Sci Technol, 27, 358-364 (1995)

Song KS, Jeon KS, Choi KS, Kim CH, Park YB, Kim JJ. Effects of storage duration with low temperature and wet condition, germination temperature and shading rate on germination of Aruncus dioicus var. kamtschaticus seeds. Korean J Medicianal Crop Sci, 23, 370-378 (2015)

Terefe NS, Matthies K, Simons L, Versteeg C. Combined high pressure-mild temperature processing for optimal retention of physical and nutritional quality of strawberries (Fragaria $\times$ Ananassa). Innovative Food Sci Emerging Technol, 10, 297-307 (2009)

Tomas-Barberan FA, Espin JC. Phenolic compounds and related enzymes as determinants of quality in fruit and vegetables. J Sci Food Agric, 81, 853-876 (2001)

Troller JA, Christian JHB. Water Activity and Food. Academic Press, New York, USA, p 52 (1978)

Zhang Q, Kim HY. DNA damage protection and antiinflammatory activity of different solvent fractions from Aruncus dioicus var. kamtschaticus. Korean J Plant Res, 27, 714-719 (2014) 